\title{
PENGARUH AKTIVITAS KEWIRAUSAHAAN TERHADAP PERTUMBUHAN USAHA PENGOLAHAN SAMPAH DI BANK SAMPAH SAWANGAN, DEPOK
}

\author{
$\underline{\text { Silvia Sari }{ }^{1} \text {, Rini Septiowati }{ }^{2} \text {, dan Sevty Wahiddirani Saputri }{ }^{3}}$ \\ 1,2,3) Program Studi Akuntansi, Fakultas Ekonomi, Universitas Pamulang \\ Jl. Surya Kencana No. 1 Pamulang, Tangerang Selatan, Indonesia \\ e-mail: ${ }^{1) d o s e n 01387 @ u n p a m . a c . i d ~}$
}

(Diterima 13 Oktober 2020/Revisi 9 Februari 2021/Disetujui 15 Maret 2021)

\begin{abstract}
One of the alternatives to reduce waste in Indonesia is the establishment of a Waste Bank. The role of waste bank actors is not the same as collectors or scavengers, they are expected to have entrepreneurial and personal characteristics. The purpose of this study is to analyze the forming factors of entrepreneurial activity in waste banks that contribute to the growth of a sustainable waste processing business. This research was conducted in Sawangan Depok. The first research stage collected primary data using a questionnaire on 111 active waste bank actors using the purposive sampling technique, then analyzed the data using Structural Equation Modeling (SEM). The results showed that the goodness fit criteria were met and the measurement variables in the model had good reliability $(C R \geq 0,70, V E \geq 0,50)$. The entrepreneurial activities of waste bank actors are most influenced by entrepreneurial characteristics $(\gamma=$ $0,70)$ and resources $(\gamma=0,63)$. The entrepreneurial characteristics of the waste bank actors are well shaped by motivation $(\lambda=0,40)$, risk $(\lambda=0,49)$, and innovation $(\lambda=1,00)$. The implication is that to grow a sustainable waste bank requires an innovative character for the waste bank actors.
\end{abstract}

Keywords: entrepreneurial activities, waste bank actors, waste processing business

\begin{abstract}
ABSTRAK
Salah satu alternatif guna mengurangi sampah di Indonesia adalah dengan dibentuknya Bank Sampah. Peran pelaku bank sampah tidak sama dengan pengumpul atau pemulung, mereka diharapkan memiliki karakteristik kewirausahaan dan karakteristik personal. Tujuan penelitian ini untuk menganalisis faktor-faktor pembentuk dalam aktivitas kewirausahaan pada bank sampah yang berkontribusi terhadap pertumbuhan usaha pengolahan sampah yang berkelanjutan. Penelitian ini dilakukan di Sawangan Depok. Tahap penelitian pertama mengumpulkan data primer menggunakan kuesioner pada 111 pelaku bank sampah yang masih aktif dengan teknik purposive sampling, selanjutnya menganalisis data dengan Structural Equation Modeling (SEM). Hasil penelitian menunjukkan kriteria goodness fit terpenuhi dan variabel pengukuran pada model memiliki reliabilitas $(\mathrm{CR} \geq 0,70, \mathrm{VE} \geq 0,50)$ yang baik. Aktivitas kewirausahaan para pelaku bank sampah dipengaruhi paling besar oleh karakteristik kewirausahaan $(\gamma=0,70)$ dan sumberdaya $(\gamma=0,63)$. Karakteristik kewirausahaan para pelaku bank sampah secara baik dibentuk oleh motivasi $(\lambda=0,40)$, risiko $(\lambda=0,49)$, dan inovasi $(\lambda=1,00)$. Implikasinya untuk menumbuhkan bank sampah yang berkelanjutan diperlukan karakter inovasi pada para pelaku bank sampah.
\end{abstract}

Kata kunci: aktivitas kewirausahaan, pelaku bank sampah, usaha pengolahan sampah

\section{PENDAHULUAN}

Jumlah sampah tiap hari terus bertambah dan sampah tidak bisa membusuk dengan sendirinya, hal ini akan menjadi masalah besar. Salah satu solusi mengurangi jumlah sampah dengan mendidirikan bank sampah. Bank sampah menurut Unilever Indonesia (2013) adalah penanganan sampah secara bersama yang mengajak para warga agar ikut serta didalamnya. Peran aktif dari para pelaku bank sampah sangat diharapkan di setiap 
bank sampah, sehingga bank sampah tidak hanya sebagai pemilahan dan pengumpul sampah tetapi bisa sebagai recycle sehingga bisa menghasilkan sebuah produk yang bernilai ekonomi.

Jumlah bank sampah di Kecamatan Sawangan Kota Depok meningkat dari dua puluh di tahun 2018 menjadi dua puluh lima di tahun 2019 (SIPSN 2013). Aktivitas para pelaku bank sampah di sawangan depok sudah bernilai ekonomi, dan bisa dikategorikan sebuah bisnis, hal ini terlihat dari banyaknya sampah yang mulai diolah dengan inovasi. Sampah plastik, kardus, kertas, botol bekas diolah dengan cara membuat kerajinan tas, anyaman kertas, dan pernak pernik lainnya. Namun apakah aktivitas yang mereka lakukan dilandasi karakter kewirausahaan dan karakter personal, dan apakah usaha bank sampah yang ada saat ini akan terus ada, berkelanjutan atau malah akan hilang dan tidak berjalan lagi? Hal ini menarik untuk diteliti, karena karakteristik kewirausahaan dan personal berperan penting dalam keberlanjutan usaha bank sampah di Indonesia. Jika tidak dilandasi dua karakter ini, peran pelaku bank sampah akan sama dengan pengumpul atau pemulung.

Sustainable juga harus diperhatikan dalam sebuah pertumbuhan usaha. Penelitian Casson et al. (2006) menemukan "hanya 20 persen bisnis yang bisa bertahan 18 hingga 24 bulan akan tumbuh sementara sisanya akan berhenti secara sukarela". Hasil penelitian Casson juga di tambahkan Bosma et al. (2011), Bosma menegaskan "sebuah usaha atau bisnis bisa mencapai tahap mapan saat umur bisnis lebih dari 36 bulan". Dari dua penelitian di atas dapat kita simpulkan bahwa tantangan seorang wirausaha selain mampu mendirikan sebuah usaha kreatif tetapi juga memiliki kemampuan menjaga pertumbuhan dan keberlangsungan usahanya. Hal ini juga menjadi isu yang menarik untuk diteliti karena banyak bank sampah yang terbentuk dan banyak juga yang tidak produktif bahkan tidak berjalan lagi.

Inovasi juga menjadi faktor kunci keberlanjutan sebuah usaha, berdasarkan peneli- tian Agbaeze (2018) menemukan inovasi berpengaruh dan berdampak pada peningkatkan kompetensi dalam pengelolaan daur ulang sampah dan limbah padat (sustainable solid) di Abuja, Nigeria.

Berdasarkan data yang di rilis kementrian lingkungan hidup, tahun 2012 tercatat ratarata ada $2 \mathrm{~kg}$ sampah yang dihasilkan satu orang perhari oleh penduduk Indonesia. Dari total sampah yang di buang, baru 42 persen yang dikelola, sisanya berserakan di jalan atau mengambang di sungai (Unilever Indo-nesia 2013). Sisa sampah plastik dan kertas yang semakin banyak ini akan menjadi sumberdaya yang bernilai, jika diolah dan proses pengolahan harus dilaksanakan dengan konsep aktivitas kewirausahaan.

Potensi sumberdaya banyaknya sampah yang bisa diolah ini juga diikuti dengan peluang bisnis. Pernak pernik olahan sampah plastik kini makin dicari semua kalangan muda mudi di Indonesia (Bisnis UKM 2014). Usaha pernak pernik olahan sampah plastik ini sangat menguntungkan karena jumlah nya yang banyak ditemui dan sebenarnya cara pengolahannya mudah kalau ditekuni bisa dijual dengan harga mahal.

Peningkatan jumlah sampah sama dengan peningkatan eksponensial jumlah penduduk, karena masing-masing individu pasti menghasilkan sisa aktivitas kegiatannya berupa barang yang tidak terpakai lagi. Jika dilihat dari sisi lain peningkatan jumlah sampah ini bisa menjadi peluang bisnis. Hal ini yang dilakukan dalam penelitian Gomathi (2018) yang menemukan peningkatan eksponensial limbah elektronik di India menjadi peluang pertumbuhan usaha industri elektronik di India. Sisa elektronik tidak lagi menjadi limbah yang meresahkan warga India. Peluang bisnis berasal dari pertumbuhan permintaan konsumen yang sangat pesat, seni pengelolaan limbah elektronik, penerapan teknologi global dengan metode perbaikan yang lebih baik, adanya peran pemegang saham dan peraturan perdagangan yang berpihak pada industri pengelolaan limbah elektronik di India 
Peran pemerintah Indonesia dalam pengelolaan sampah terlihat dengan meluncurkan UU No. 18 tahun 2008 mengamanatkan pengelolaan sampah dengan prinsip 3-R yaitu "pendekatan kumpul - angkut - buang diganti menjadi pemilahan - pengumpulan pengangkutan pengolahan pemprosesan. Oleh karena itu, pada aspek pengelolaan sampah sendiri, dapat disimpulkan bahwa pemerintah memiliki peran dalam pengelolaan sampah. Pemerintah menjadikan bank sampah sebagai strategi penerapan 3-R" (Unilever Indonesia 2013).

Berdasarkan latar belakang kondisi yang sudah dipaparkan diatas, maka sejauh mana karakteristik kewirausahaan, karakteristik personal, peluang bisnis, dan ketersediaan sumberdaya yang dimiliki para pelaku bank sampah di Sawangan Depok mempengaruhi aktivitas kewirausahaan? Apakah faktorfaktor diatas berkontribusi terhadap pertumbuhan usaha pengolahan sampah yang berkelanjutan? Kedua pertanyaan diatas akan dibahas dalam penelitian ini.

Penelitian ini bertujuan untuk mengidentifikasi dan menganalisis faktor-faktor pembentuk dalam aktivitas kewirausahaan pada bank sampah yang berkontribusi terhadap pertumbuhan usaha pengolahan sampah yang berkelanjutan di Sawangan Depok.

Faktor - faktor pembentuk dalam aktivitas kewirausahaan berdasarkan teori -teori yang ada dapat dikelompokkan berdasarkan faktor internal (karakteristk personal dan karakteristik kewirausahaan) serta faktor eksternal yatu (peluang bisnis dan ketersediaan sumber daya). Keempat variabel laten ini nantinya akan dilihat bagaimana pengaruhnya dalam membentuk aktivitas kewirausahaan bank sampah di Sawangan Depok.

Karakteristik mengandung pengertian sebuah reputasi seseorang, kualitas positif yang dimiliki seseorang, serta kepribadian yang eksentrik sehingga membuatnya menarik dan atraktif (Sumantri 2013).

Karakter pengusaha (entrepreneurial characteristics) dibagi ke dalam tiga kategori, yaitu: (1) karakteristik demografis, seperti gender pria atau wanta, usia, suku, dan latar orangtua yang dihubungkan pada keberhasilan sebuah usaha; (2) karakteristk psikologis dan prilaku wirausaha, seperti motif berprestasi, intenal locus of control, take a risk, kreatif, dan inovatif, dalam start-up, keberlanjutan dan keberhasilan usaha; (3) faktor human capital, seperti pendidikan, pengalaman bekerja, pengalaman membuka usaha, pelatihan keterampilan dan teknis, serta jaringan wirausaha atau hubungan sosial, yang mempengaruhi kemampuan pengusaha menyerap informasi sebagai modal usahanya (Li 2009).

Penelitian ini menggunakan karakteristik kewirausahaan psikologi yaitu motivasi, risiko dan inovasi yang dimiliki para pelaku bank sampah dalam menjalankan usaha bank sampahnya. Karakter ini dipilih sebab karakter psikologi dianggap paling tepat menggambarkan karakter jiwa wirausaha pada para aktor bank sampah sehingga nantinya akan berpengaruh terhadap keberlanjutan usaha bank sampah.

Karakteristik personal yang dipakai pada penelitian ini berdasarkan penelitian terdahulu adalah usia, pendidkan, pengalaman usaha, pelatihan dan latar keluarga (Li 2009; Sumantri 2013; dan Puspitasari 2013).

Kewirausahaan menurut Timmons dan Spinelli (2007) diawali dengan peluang, dilengkapi dengan sumberdaya, dan dikokohkan oleh tim. Berdasarkan teori ini penting melihat peluang bisnis karena peluang bisnis menjadi awal proses kewirausahaan. Peluang dk Karakteristik peluang diukur dari 3 kriteria seperti market demand, market structure and size, serta margin analysis.

Peluang menurut Bygrave dan Zacharakis (2010) dan Hubeis (2005) terdiri atas: kemajuan technology, goverment, prospek pasar dan lembaga keuangan. Mengacu pada penelitian yang sebelumnya peluang dalam penelitian ini diukur dari potensi permintaan pasar, dukungan goverment, dukungan lembaga keuangan, dan kemajuan technology.

Model kesuksesan aktivitas kewirausahaan yang menggaris bawahi isu-isu yang berhubungan dengan kombinasi SDM, assets, 
faktor produksi dan finansial resources ternyata mampu membangun wirausaha yang sukses" (Timmons dan Spinelli 2007). Sumberdaya dalam penelitian ini melihat dari dua poin penting yaitu sumberdaya modal dan ketersediaan sumberdaya manusia.

Berdasarkan pengertiannya, kewirausahaan sangat terkait dengan aktivitas kewirausahaan. Pengertian kewirausahaan menurut Ahmad dan Seymour (2008) adalah nilai yang dihasilkan dari entrepreneurial activity melalui pengolahan sumberdaya, kemampuan membaca peluang, kondisi bisnis dan lingkungan global.

Menurut Suryana (2003) kewirausahaan adalah kecakapan pada proses penciptaan nilai tambah dengan cara pengolahan sumberdaya dengan teknik baru dan membuka peluang kesuksesan melalui: (1) new technology; (2) new knowledge; (3) perbaikan product and service yang ada; (4) penemuan cara-cara baru untuk menghasilkan barang lebih banyak dengan sumberdaya lebih efisien".

Aktivitas kewirausahaan dalam pengolahan sampah sangat penting guna menciptakan nilai tambah dan mengurangi jumlah sampah yang ada. Wirausaha menurut Joseph Schumpeter dikutip pada buku Casson et al. (2006) merupakan pribadi yang sangat inovatif dalam menemukan/mengembangkan, process atau technology baru, new market, sumber daya baru, dan institusional baru yang berhubungan dengan risiko dan inovasi. Banyak perusahaan yang terus tumbuh dengan mempertahankan inovasinya dan banyak juga yang gagal dalam perjalanannya. Kegagalan disebabkan kurangnya kemampuan dalam bersaing dan proses produksi yang tidak efisien". Sehingga aktivitas kewirausahaan pada penelitian ini dilihat dari dayasaing dan daya produksi.

Pertumbuhan usaha tidak hanya kemampuan dalam memulai usaha tetapi juga mempertahankan keberlanjutan usaha. Okpara (2007) menegaskan factor penentu usaha tetap bisa bertahan adalah usaha yang tetap kreatif dan inovatif karena mereka senantiasa melakukan hal-hal baru atau melakukan halhal biasa dengan cara yang luar biasa.

Tahap pertumbuhan dan perkembangan usaha diambil dari model penelitian Bygrave dan Zacharakis (2010) yaitu pertumbuhan usaha berdasarkan skala usaha dan tingkat pendapatan.

Analisis SEM memiliki keistimewaan dari pada regresi pada umumnya. Regresi biasa melakukan analisa hubungan antara variabelvariabel yang dapat dilihat secara langsung. Sementara model SEM melakukan analisa hubungan antara variabel-variabel yang tidak dapat dilihat secara langsung. Analisis SEM juga dapat memeriksa dan membenarkan suatu teori. Maka dari itu, hal pertama dalam penggunaan SEM yaitu membuat sebuah model dugaan berisi model struktural dan model pengukuran dalam bentuk path diagram sesuai teori (Wijanto 2008).

\section{METODE}

Penelitian ini tergolong penelitian deskriptif kuantitatif. Analisis data primer yang dilakukan dengan sebaran kuesioner pada pelaku bank sampah di Sawangan Depok dengan teknik purposive sampling, yaitu menggunakan kriteria pelaku bank sampah yang tetap melakukan kegiatan di bank sampah dan pernah mengikuti kegiatan kewirausahaan di bank sampah. Sumber data didapatkan dari observasi kelapangan, wawancara dan dokumentasi kepada pelaku bank sampah yang berada di Sawangan Depok Provinsi Jawa Barat.

Tahap awal penelitian adalah merekap data yang telah dikumpulkan dan diolah menggunakan program MS Excel 2016. Tahap berikutnya adalah mengolah data dari MS Excel 2016 pada program LISREL 8.30 kemudian hasilnya dianalisis menggunakan metode SEM (Structural Equation Modelling). Penelitian ini dilakukan dengan pengukuran skala likert menggunakan lima skala/skor. Semakin tinggi skor (jika jawaban lima) berarti penilaian dari jawaban responden terhadap suatu objek semakin positif. Sebalik- 
nya Semakin rendah skor (jika jawaban satu) berarti penilaian dari jawaban responden terhadap suatu objek semakin negative. Hasil jawaban responden yang dalam angka-angka nanti akan dideskripsikan dengan kondisi yang ada dilapangan.

Analisis SEM pada peneltian ini memuat: empat variabel laten eksogen yaitu karakteristik kewirausahaan (X1), karakteristik personal (X2), peluang (X3), dan sumberdaya (X4); dua variabel laten endogen yaitu aktivitas kewirausahaan (Y1) dan pertumbuhan usaha (Y2); dan 18 variabel manifest. Rincian variabel laten dan manifest terdaapat pada Tabel 1. Pembahasan analisis deskriptif ini akan dikelompokkan menjadi faktor internal (X1 \& X2) dan faktor eksternal (X3 \& X4) untuk mempermudah melihat pengaruh hubungan faktor internal dan faktor eksternal ke Y1, sekaligus pengaruh Y1 ke Y2.

\section{HASIL DAN PEMBAHASAN}

Analisis SEM pada penelitian ini menjelaskan hubungan aktivitas kewirausahaan dan pertumbuhan usaha dari para pelaku Bank sampah dan sealiagus mencari faktor yang paling berpengaruh dalam membentuk pertumbuhan usaha pengolahan sampah. Pendekatan analisis SEM yang dipilih adalah pendekatan one step approach yaitu "komponen model pengukuran dan struktural di estimasi secara simultan dalam sebuah analisis tunggal" (Wijanto 2008).

Pada pengolahan analisis SEM tahap pertama dihasilkan model awal yang mengandung offending estimates yaitu pada model terdapat nilai-nilai estimasi yang melewati ambang batas analisis, seperti error varian bernilai negative dan nilai $t$ value kurang dari 1.96. Oleh karena ini dilakukan proses respesifikasi. Hasil pada pengolahan tahap kedua setelah respesifikasi sudah menunjukkan model SEM yang goodfit yaitu tidak ada lagi nilai estimasi yang melewati ambang batas. Model ini dapat lihat pada Gambar 1. "Respesifikasi dilakukan dengan memanfaatkan saran yang ada pada modification indeks yaitu menambahkan error covariances pada dua error variances (Wijanto 2008).

Validitas model yang telah melewati tahap respesifikasi terlihat bagus, artinya model respesifikasi ini dapat mengukur sesuai harapan dan mampu menjelaskan hubungan antar variabel. Variable yang memiliki validitas

Tabel 1. Variabel Laten dan Manifes Model Persamaan Struktural

\begin{tabular}{|c|c|}
\hline Variabel Laten & Variabel Manifest \\
\hline Eksogen & 1. $\quad$ Motif wirausaha (X1.1) \\
\hline \multirow[t]{2}{*}{ Karakteristik Kewirausahaan (X1) } & 2. Keberanian menghadapi risiko (X1.2) \\
\hline & 3. Inovasi yang dimiliki(X1.3) \\
\hline \multirow[t]{5}{*}{ Karakteristik Personal (X2) } & 4. Kematangan usia $(X 2.1)$ \\
\hline & 5. Pengalaman $(X 2.2)$ \\
\hline & 6. Pendidikan (X2.3) \\
\hline & 7. Pelatihan $(\mathrm{X} 2.4)$ \\
\hline & 8. Dukungan kluarga (X2.5) \\
\hline \multirow[t]{4}{*}{ Peluang (X3) } & 9. Potensi pasar $\left(\mathrm{X}_{3.1}\right)$ \\
\hline & 10. Peran Goverment $\left(X_{3.2}\right)$ \\
\hline & 11. Peran perbankan $\left(X_{3.3}\right)$ \\
\hline & 12. Perkembangan technology $\left(X_{3.4}\right)$ \\
\hline \multirow[t]{2}{*}{ Sumberdaya $(X 4)$} & 13. Ketersediaan modal/assets $\left(X_{4.1}\right)$ \\
\hline & 14. Ketersediaan SDM $\left(\mathrm{X}_{4.2}\right)$ \\
\hline Endogen & 15. Dayasaing (Y1.1) \\
\hline Aktivitas kewirausahaan (Y1) & 16. Daya Produksi (Y1.2) \\
\hline \multirow[t]{2}{*}{ Pertumbuhan Usaha (Y2) } & 17. Skala usaha (Y2.1) \\
\hline & 18. Tingkat pendapatan $(\mathrm{Y} 2.2)$ \\
\hline
\end{tabular}




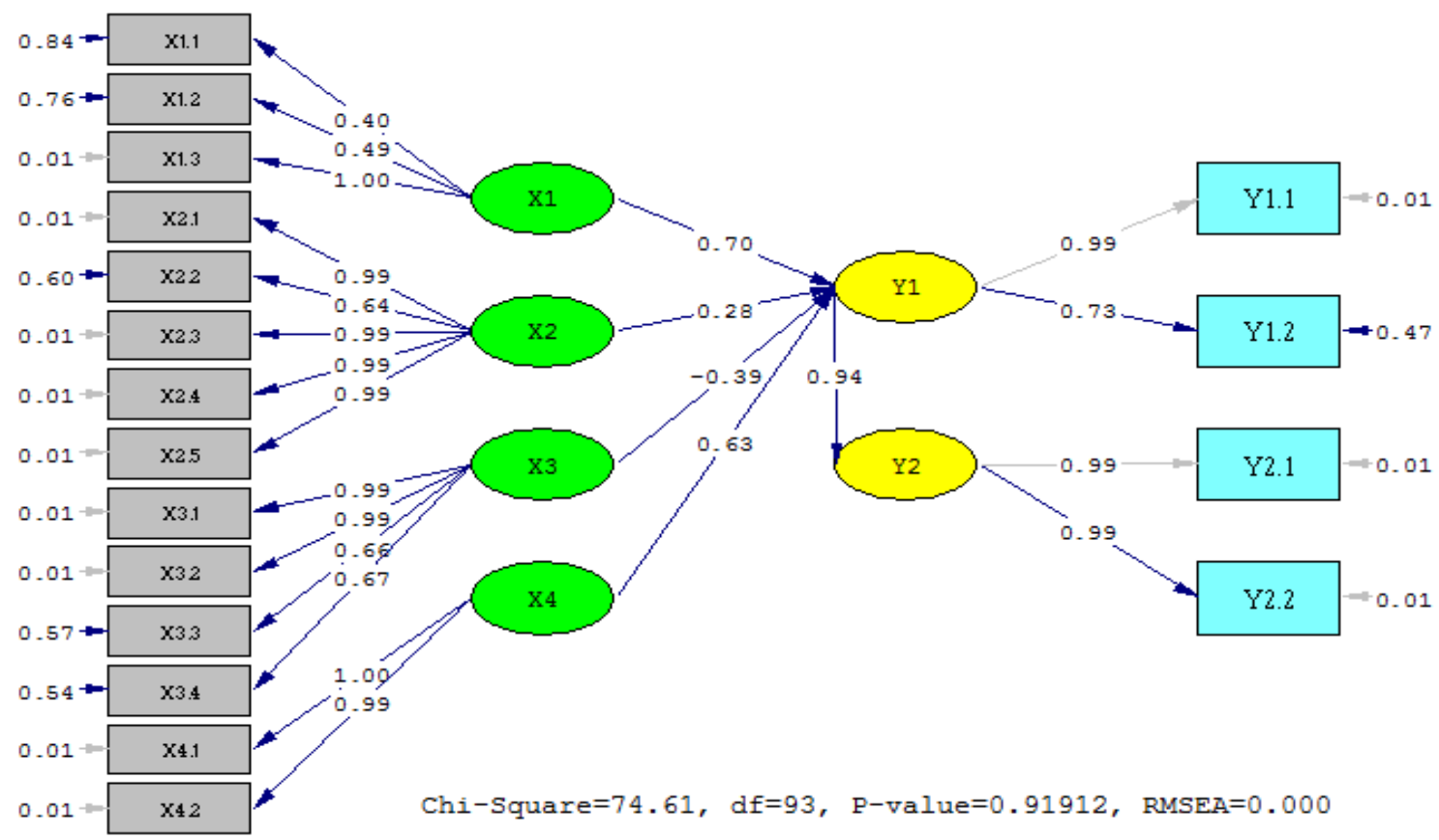

Gambar 1. Path Diagram Estimate Model Respesifikasi

yang baik jika nilai t- value besar sama dari 1.96 saat $\mathrm{a}=0.05$ dan nilai standar loading faktor besar sama dari 0.3" (Wijanto 2008). Validitas model ini diperlihatkan oleh Gambar 2.
Hasil estimasi pada Gambar 1 terlihat model sudah memenuhi kriteria uji kecocokan model dengan kategori baik (good fit). Kriteria ini akan dijelaskan pada Tabel 2. "Good fit artinya model dapat menggambarkan dengan baik hubungan antara data dilapangan de-

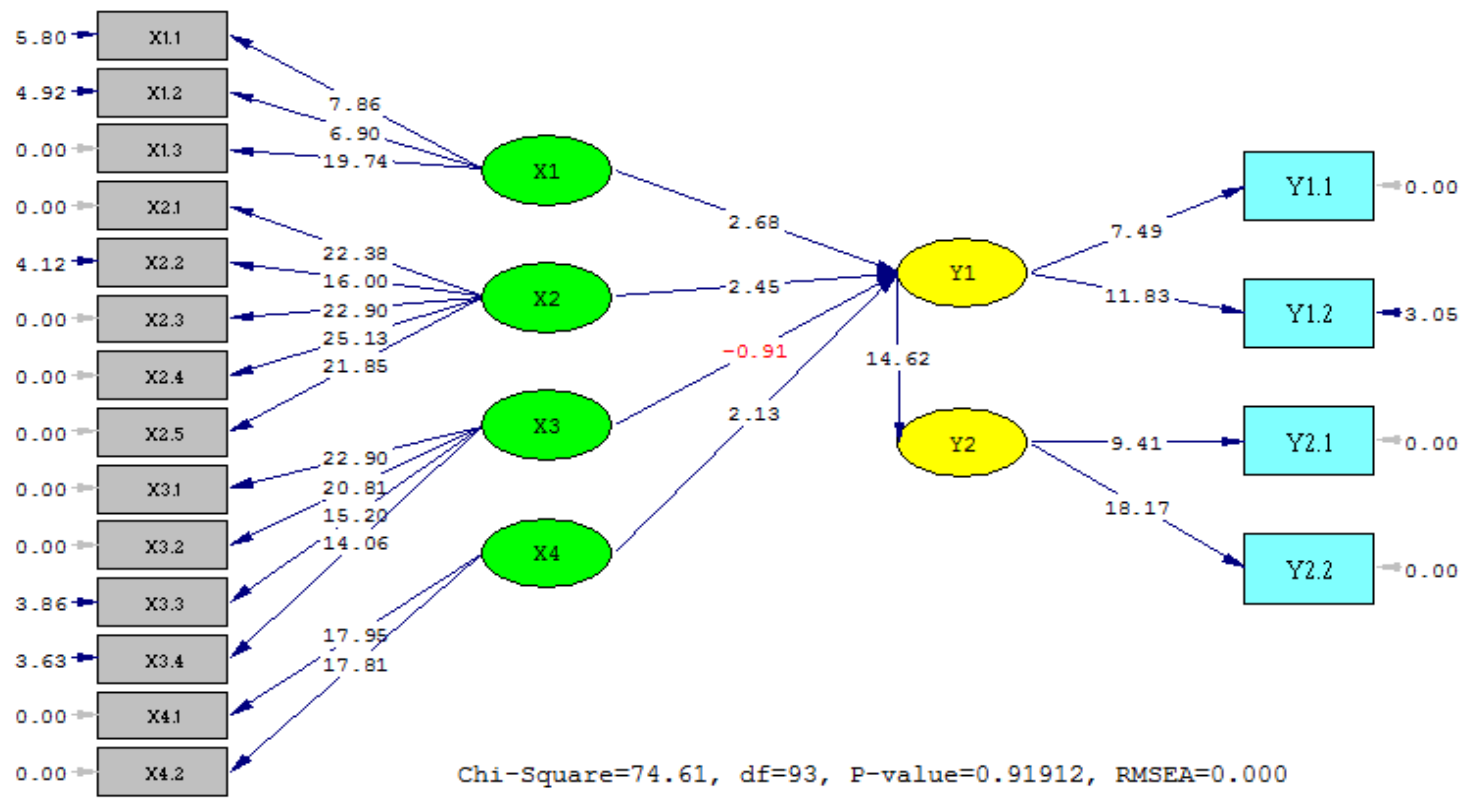

Gambar 2. Path Diagram Model T-Value 
Tabel 2. Hasil Uji Good Fit Model

\begin{tabular}{lccc}
\multicolumn{1}{c}{ Goodness-of-Fit } & Cutt-off-Value & Hasil & Kecocokan \\
\hline Significance Probability(P-value) & $\geq 0,05$ & 0,92 & Good Fit \\
RMR(Root Mean Square Residual) & $\leq 0,05$ atau $\leq 0,1$ & 0,075 & Good Fit \\
RMSEA(Root Mean square Error of Approximation) & $\leq 0,08$ & 0,00 & Good Fit \\
GFI(Goodness of Fit) & $\geq 0,90$ & 0,99 & Good Fit \\
AGFI(Adjusted Goodness of Fit Index) & $\geq 0,90$ & 0,98 & Good Fit \\
CFI (Comparative Fit Index) & $\geq 0,90$ & 1,00 & Good Fit \\
NFI (Normed Fit Index) & $\geq 0,90$ & 0,98 & Good Fit \\
\hline
\end{tabular}

ngan teori yang digunakan dalam penelitian (Wijanto 2008).

Tabel 3 menunjukkan hasil uji reabilitas model pengukuran. Pada tabel ini terlihat model memiliki variance extracted (VE) dan construct reliability (CR) sebagian besar sudah memenuhi kriteria ambang batas yaitu CR kurang dari 0.70 dan VE kecil dari 0,05. Berdasarkan uji reliability ini dapat kita simpulkan variabel-variabel manifest yang berjumlah jumlah 18 mengukur variable latennya dengan tepat dan juga konsisten.

\section{PENGARUH FAKTOR INTERNAL TERHADAP AKTIVITAS KEWIRAUSAHAAN PELAKU BANK SAMPAH di SAWANGAN DEPOK}

Berdasarkan model pada Gambar 1 diketahui bahwa aktivitas kewirausahaan dipengaruhi oleh faktor internal dari karakteristik kewirausahaan $(\gamma=0,70)$ dan karakteristik personal $(\gamma=0,28)$. Karakteristik kewirausahaan terbukti mempengaruhi aktivitas kewirausahaan dengan nilai paling besar. Hal ini menunjukkan untuk meningkatkan aktivitas kewirausahaan para pelaku bank sampah maka karakteristik kewirausahaan yang mereka miliki sekarang harus terus dipertahankan dan diasah. Karakteristik kewirausahaan yang dimiliki para pelaku bank sampah di Sawangan Depok secara rinci akan dibahas sebagai berikut:

1) Karakteristik Kewirausahaan

Aktivitas kewirausahaan para pelaku bank sampah signifikan dipengaruhi oleh karakteristik kewirausahaan ( $\mathrm{t}$-value $=2,68$ ). Karakteristik kewirausahaan yang membentuk aktivitas kewirausahaan para pelaku bank sampah dibangun oleh inovasi $(\lambda=1,00)$, risiko $(\lambda=0,49)$ dan motivasi $(\lambda=0,40)$. Semakin tinggi inovasi, keberanian menghadapi resiko dan motivasi berwirausaha yang dimiliki para pelaku bank sampah, cenderung aktivitas kewirausahaannya semakin meningkat. Artinya jika para pelaku bank sampah melakukan pengolahan sampah dengan kreatifitas, inovasi, Sampah plastik yang sering dikreasikan adalah sedotan plastik, botol plastik, gelas plastik, botol oli, sendok plastik dan sejenisnya. Sampah plastik, sampah kertas dan botol bekas bisa menjadi produk yang bernilai seni dan bisa bermanfaat maka aktivitas yang mereka lakukan bernilai entrepreneur, motivasi yang melandasi mereka melakukan usaha di bank sampah bukan hanya menjadi pengumpul sampah, tetapi melakukan mereka adalah pahlawan lingkungan, seorang perwira yang mampu mengubah sampah menjadi produk unik yang punya nilai tambah dan nilai jual.

Tabel 3. Hasil Uji Reliabilitas Model Pengukuran

\begin{tabular}{lrccccc}
\hline & $\begin{array}{c}\left(\sum \text { std }\right. \\
\text { Load) }\end{array}$ & $\sum$ ej & CR & $\begin{array}{c}\sum(\text { std } \\
\text { Load) }\end{array}$ & VE & Reabilitas \\
\hline Karakteristik kewirausahaan & 3,57 & 1,61 & $0,69<0,70$ & 1,40 & $0,47<0,05$ & Cukup Baik \\
Karakteristik personal & 21,16 & 0,64 & $0,97 \geq 0,70$ & 4,33 & $0,87 \geq 0,05$ & Baik \\
Peluang & 10,96 & 1,13 & $0,91 \geq 0,70$ & 2,84 & $0,72 \geq 0,05$ & Baik \\
Sumberdaya & 3,96 & 0,02 & $0,99 \geq 0,70$ & 1,98 & $0,99 \geq 0,05$ & Baik \\
Aktivitas Usaha & 2,96 & 0,48 & $0,86 \geq 0,70$ & 1,51 & $0,76 \geq 0,05$ & Baik \\
Pertumbuhan usaha & 3,92 & 0,02 & $0,99 \geq 0,70$ & 1,96 & $0,99 \geq 0,05$ & Baik \\
\hline
\end{tabular}


Inovasi menjadi variable manifest yang nilainya paling besar dalam karakteristik kewirausahaan yang mempengaruhi aktivitas kewirausahaan para pelaku bank sampah. Pentingnya inovasi pada ciri seorang wirausaha juga ditegaskan oleh oleh Drucker (1985), dalam kutipannya menyebutkan "wirausahawan sangat berkaitan dengan inovasi". Hasil penelitian Agbaeze (2018) juga menemukan inovasi berpengaruh positif signifikan terhadap kapasitas daur ulang sampah padat $(p<0,01)$ di Abuja, Nigeria. Sebagai faktor yang mempengaruhi inovasi kewirausahaan dari para pelaku bank sampah yang inovatif akan mendorong efisiensi dan efektivitas dalam pengelolaan sampah.

\section{2) Karakteristik Personal}

Aktivitas kewirausahaan para pelaku bank sampah dipengaruhi oleh karakterisik personal dengan nilai $t$-value $=2,45$. Karakteristik ini dibentuk dari variable manifes kematangan usia $(\lambda=0,99)$, pendidikan formal $(\lambda=0,99)$, peran keluarga $(\lambda=0,99)$ dan keikutsertaan dalam pelatihan $(\lambda=0,99)$. Artinya aktivitas kewirausahaan dari para pelaku bank sampah di Sawangan Depok akan semakin tinggi jika masing-masing pelaku bank sampah adalah seorang individu yang berpendidikan, matang dari segi usia, terlatih dan didukung oleh keluarga.

Kematangan usia penting dalam menentukan sikap dan pilihan seseorang. Kematangan usia bukan hal yang kuantitatif, bukan berarti semakin tua semakin matang usianya. Keputusan untuk menjadi pengusaha apa lagi pengusaha bank sampah, butuh pemikiran yang matang, kebijakan berpikir dan kedewasaan dalam sikap dan tanggung jawab terhadap lingkungan.

Pendidikan formal berperan dalam kemampuan berfikir, mengambil keputusan dan menyerap informasi, sehingga pendidikan formal yang tinggi akan menunjang keberhasilan seorang wirausaha. Kaitan pendidikan formal dengan aktivitas wirausaha sudah dibuktikan dalam penelitian Puspitasari (2013) yang menegaskan ada hubungan pendidikan dengan aktivitas kewirausahaan.
Karakteristik personal direfleksikan oleh variable manifest pelatihan. Noersasongko (2005) dalam penelitiannya menegaskan wirausaha dengan seringnya melakukan pelatihan cendrung lebih sukses ketimbang wirausaha tanpa mengikuti. Kita dapat menyimpulkan pelatihan berdampak pada munculnya keinginan mau menjadi seorang wirausaha. Hasil penelitian Agbaeze (2018) juga menemukan pelatihan dan pendidikan non formal meningkatkan kompetensi dalam perlakuan limbah padat berkelanjutan di Abuja, Nigeria.

Hasil penelitian Solihin (2018) juga menunjukkan bahwa "ada hubungan antara tingkat partisipasi dengan keberlanjutan pengolahan sampah pada bank sampah di Desa Ragajaya, Kabupaten Bogor, sisi lain partisipasi ibu rumah tangga dapat meningkat jika intensitas pendidikan nonformal dan tingkat bantuan ditingkatkan". Artinya pengolahan sampah melalui bank sampah dapat mengatasi permasalahan lingkungan secara berkelanjutan jika warga dan ibu rumah tangga berpartisipasi aktif dalam kegiatan bank sampah.

Variable manifest dukungan keluarga menjadi variabel keempat yang mereflekskan karakteristk personal. Hasil penelitian ini sejalan dengan Brush et al. (2010) yang menegaskankan indikator keluarga berperan pada individu sebagai pengusaha. Sehingga walaupun yang aktif di bank sampah rata-rata adalah para wanita dan ibu-ibu rumah tangga, karena mereka lebih sering mengurusi sampah dirumah akan tetapi peran dan dukungan suami serta anak-anaknya sangat penting, sehingga semua bisa bekerja sama dalam hal merawat lingkungan dan pengelolaan sampah yang lebih baik.

\section{PENGARUH FAKTOR EKSTERNAL TERHADAP AKTIVITAS KEWIRAUSAHAAN PELAKU BANK SAMPAH}

Faktor eksternal yang mempengaruhi aktivitas kewirausahaan para pelaku bank sampah hanya sumberdaya ( $\mathrm{t}$-value $=2,13$ ). Aktivitas usaha yang dilakukan oleh pelaku 
bank sampah tidak dipengaruhi secara signifikan oleh peluang, karena memiliki | thitung $\mid<\mathrm{t}$-tabel $(1,96)$ yaitu (t-value $=0,91)$. Akan tetapi, variabel peluang tidak dihilangkan dari model pada Gambar 1 dikarenakan secara keseluruhan komponen variabel peluang tetap berkontribusi membentuk model yang baik pada Gambar 1. Berikut penjelasan masing-masing variable manifest dari peluang dan sumberdaya.

\section{1) Peluang}

Variabel peluang memiliki nilai faktor loading negative $(\gamma=-0,91)$, akan tetapi variabel ini memiliki nilai t-hitung yang tidak signifikan sehingga aktivitas kewirausahaan tidak signifikan dibentuk oleh variabel ini. Peluang terbentuk dari indikator besarnya potensi permintaan pasar pada produk olahan sampah, dukungan program-program pemerintah, kemajuan teknologi pengolahan yang bisa digunakan, dukungan perbankan masih lemah dalam mempengaruhi aktivitas usaha. Peluang permintaan pasar pada produk dari olahan kerajinan tangan dari sampah, peran pemerintah dalam bantuan modal dan pelatihan serta peluang pendanaan perbankan untuk UMKM dari jawaban responden sangat kecil dan hampir tidak berarti dalam mempengaruhi aktivitas usaha pelaku bank sampah.

Hasil penelitian menunjukkan pengaruh goverment, bank, technology dan demand market belum berpengaruh pada pelaku bank sampah di Sawangan Depok dan mereka tidak terampil dalam memanfaatkannya. Kondisi ini di tegaskan dengan pendapat Pambudy (2010) dalam tulisannya pembangunan ekonomi Indonesia saat ini masih pada tahap 1 yaitu menggunakan SDM yang belum terampil. Hal ini terlihat pada nilai tambah yang dihasilkan masyarakat masih rendah. Artinya tingkat pengolahan yang mereka lakukan nilai tambahnya masih kecil sehingga peluang tingginya permintaan pasarnya tidak begitu berarti walau pun sudah ada dukungan program-program dari pemerintah.

Penelitian Wulandari (2017) tentang Model Pengelolaan Sampah dalam Meningkat- kan ekonomi lokal di Malang juga menemukan masyarakat mengharapkan lebih banyak dukungan dari pemerintah untuk memperbaiki mekanisme bank sampah dan model penetapan harga sampah yang lebih baik

Pada penelitian ini peluang tidak berpengaruh signifikan pada aktivitas dan pertumbuhan usaha namun pada penelitian Gomathi (2018) menemukan peluang bisnis yang tersedia menghasilkan pertumbuhan yang luar biasa dalam industri elektronik seiring dengan pertumbuhan eksponensial limbah elektronik di India. Hal ini telihat dari pertumbuhan permintaan konsumen yang sangat pesat, seni pengelolaan limbah elektronik di India dengan penerapan teknologi global telah dilakukan dengan metode perbaikan yang lebih baik, adanya peran pemegang saham dan peraturan perdagangan yang berpihak pada industri pengelolaan limbah elektronik di India

\section{2) Sumberdaya}

Aktivitas usaha pada pelaku bank sampah signifikan dipengaruhi oleh sumberdaya (tvalue $=2,13$ ). Sumberdaya dalam hal ini diartikan sebagai banyaknya sampah, ketersediaan modal, dan sumberdaya sklill SDM untuk memulai sebuah aktivitas usaha. Variabel laten sumberdaya yang mempengaruhi aktivitas usaha pada pelaku bank sampah dijelaskan oleh sumberdaya modal $(\lambda=1,00)$ dan sumberdaya manusia $(\lambda=0,99)$.

Variabel laten sumber daya mempunyai nilai loading tertinggi kedua setelah karakteristik kewirausahaan dalam mempengaruhi aktivitas usaha. Banyaknya antusias dari ibuibu rumah tangga untuk ikut berpastisipasi dalam bank sampah akan menjadi modal utama dalam menjalankan kegiatan pengolahan sampah. Pengolahan bank sampah yang sebenarnya tidak butuh modal besar, jika dikelola dengan baik akan menghasilkan provit yang sangat bagus.

Hasil penelitian ini juga menunjukkan banyaknya sumberdaya manusia, khususnya ibu rumah tangga yang bisa dikelola untuk mangatasi permasalahan sampah di Indonesia. Selain mengatasi sampah aktivitas pe- 
ngolahan sampah juga bisa menjadi program pemberdayaan perempuan miskin seperti yang dilakukan pada penelitian Mujahiddin (2018) yang menegaskan program Bank Sampah berpengaruh positif dan signifikan terhadap Pemberdayaan Perempuan Miskin di Kelurahan Sicanang Belawan Medan".

Program bank sampah serta pemberdayaan perempuan di Medan ini bisa menjadi contoh untuk bank sampah yang lain, termasuk bank sampah Sawangan Depok sehingga dengan adanya aktivitas usaha bank sampah oleh para pelaku bank sampah di Sawangan Depok bisa menambah pendapatan dan sekaligus mengatasi permasalahan sampah.

Hasil penelitian Wulandari (2017) menunjukkan bahwa "model kegiatan bank sampah bermanfaat dalam mewujudkan sekitaran yang bersih dan juga berdampak pada perekonomian daerah meningkatkan pendapatan ibu rumah tangga di sekitar bank sampah".

\section{PENGARUH AKTIVITAS}

\section{KEWIRAUSAHAAN PELAKU BANK SAMPAH TERHADAP PERTUMBUHAN USAHA BANK SAMPAH}

Pada Gambar 1 terlihat bahwa dari hasil pengolahan SEM terbukti variable pertumbuhan usaha dipengaruhi oleh variabel aktivitas kewirausahaan sebesar $\beta=0,94$ dan tvalue $=14,62$. Artinya untuk bisa mengatasi permasalah sampah kita harus meningkatkan pertumbuhan usaha pengolahan sampah dengan cara giat melakukan aktivitas kewirausahaan. Karakterisitik kewirausahaan, karakteristik personal, dan sumberdaya signifikan mempengaruhi aktivitas kewirausahaan. Pada Tabel 4 akan digambarkan simpulan hasil pengolahan SEM pada penelitian ini.
Berdasarkan hasil pengolahan SEM menunjukan karakteristik kewirausahaan mempunyai nilai yang terbesar dalam mempengaruhi aktivitas kewirausaha. Berdasarkan hal ini dapat kita simpulkan, para pelaku bank sampah di Sawangan Depok memiliki karakter wirausaha dan aktivitas usaha yang telah dilakukan terbukti menghasilkan pertumbuhan usaha yang bernilai provit.

Aktivitas kewirausahaan dari para pelaku bank sampah di Sawangan Depok terbukti berpengaruh positif dan signifikan pada pertumbuhan usaha dari pelaku Bank Sampah dengan asumsi ceteris paribus. Hal ini berarti solusi untuk permasalahan sampah adalah dengan mengiatkan aktivitas kewirausahaan para pengelola bank sampah.

Para pengelola bank sampah di Sawangan Depok juga terbukti berkarakter wirausaha sehingga bisa dijadikan sebagai bank sampah percontohan dan pahlawan lingkungan yang berkarakter wirausaha guna mengatasi permasalahan sampah yang semakin rumit.

\section{KESIMPULAN DAN SARAN}

\section{KESIMPULAN}

Berdasarkan hasil analisis SEM dapat disimpulkan :

1. Karakteristik kewirausahaan adalah faktor pembentuk terbesar dalam aktivitas kewirausahaan pada bank sampah yang berkontribusi terhadap pertumbuhan usaha pengolahan sampah yang berkelanjutan di Sawangan Depok $(\gamma=0,70)$. Faktor pembentuk aktivitas kewirausahaan lainnya adalah sumberdaya dan karakteristik personal.

2. Karakteristik kewirausahaan para pengelola bank sampah terbentuk oleh motivasi

Tabel 4. Simpulan Model Estimasi SEM

\begin{tabular}{lccc}
\hline Path & Estimasi & t-value & Kesimpulan \\
\hline Karakteristk kewirausahaan $\rightarrow$ Aktivitas kewirausahaan & 0,70 & $2,68^{\mathrm{a}}$ & significant \\
Karakteristik personal $\rightarrow$ Aktivitas kewirausahaan & 0,28 & $2,45^{\mathrm{a}}$ & significant \\
Sumberdaya $\rightarrow$ Aktivitas kewirausahaan & 0,63 & $2,13^{\mathrm{a}}$ & significant \\
Aktivitas kewirausahaan $\rightarrow$ Pertumbuhan usaha & 0,94 & $14,62^{\mathrm{a}}$ & Significant \\
\hline
\end{tabular}


$(\lambda=0,40)$, keberanian menghadapi resiko $(\lambda=0,49)$, dan inovasi $(\lambda=1,00)$. sehingga para pelaku bank sampah di Sawangan Depok berkarakter wirausaha. Aktivitas para pelaku bank sampah ini terbukti $(\beta=0,94)$ menumbuhkan usaha pengolahan bank sampah yang bernilai entrepreneurship, sehingga dapat kita simpulkan mereka bukan cuma pengumpul sampah atau pemulung.

\section{SARAN}

Saran dari hasil penelitian ini adalah :

1. Memperbanyak inovasi dan pelatihan wirausaha kepada para pelaku bank sampah sebagai saran utama guna memperbanyak bank sampah yang memiliki karakter wirausaha

2. Peningkatan usaha pengolahan pada bank sampah sehingga bisa terus berkelanjutan sebagai solusi dalam mengatasi permasalahan sampah.

\section{DAFTAR PUSTAKA}

Agbaeze. 2018. Influence of Entrepreneurial Innovation on Sustainable Solid: Waste Recycling in Abuja, Nigeria. Periodica Polytechnica Social and Management Sciences. DOI 10.3311

Ahmad N, Seymour RG. 2008. Defining entrepreneurial activity: definitions supporting frameworks for data collection. OECD Statistics Working Papers. 2008(1):1-19.

Bisnis UKM. 2014. Bisnis daur ulang sampah plastik bisnis untuk masa depan. .https://bisnisukm.com/bisnis-daurulang-sampah-plastik-usaha-masadepan.html.

Bosma N, Wennekers S, Amorós JE. 2011. Extended Report: Entrepreneurs and Entrepreneurial Employees Across the Globe. London (GB): Global Entrepreneurship Research Association.

Brush CG, de Bruin A, Gatewood EJ, Henry C. 2010. Women Entrepreneurs and the Globa
Environment for Growth. Northampton (US): Edward Elgar Publishing Inc.

Bygrave WD, Zacharakis A. 2010. The Portable MBA in Entrepreneurship: Fourth Edition. New Jersey (US): John Willey \& Sons Inc.

Casson M, Yeung B, Basu A, Wadeson N. 2006. The Oxford Handbook of Entrepreneurship. New York (US): Oxford University Press Inc.

Drucker PF. 1985. Inovasi dan Kewiraswataan Praktek dan Dasar-Dasar. Rusjdi Naib, penerjemah. Jakarta (ID): Erlangga. Terjemahan dari: Innovation and Entrepreneurship.

Gomathi N, Rupesh PL. 2018. Study on Business Opportunities Extracted From E-Waste A Review. International Journal of Engineering \& Technology. 7 (2.33) (2018) 1106-1109

Hubeis M. 2005. Manajemen Kreativitas dan Inovasi Dalam Bisnis. Jakarta (ID): Hecca Publising.

Li X. 2009. Entrepreneurial Competencies as An Entrepreneurial Distinctive: An Examination of The Competency Approach in Defining Entrepreneurs. [Thesis]. Institutional Knowledge at Singapore Management University.

Mujahiddin, Tanjung Y, Augus E. 2018. Analysis of the Effect of Waste Bank Program on Empowerment of Poor Women in Kelurahan Sicanang Belawan Medan. Budapest International Research and Critics Institute-Journal (BIRCIJournal). Volume I, No 3, October 2018, Page: 105-113

Noersasongko E. 2005. Analisis Pengaruh Karakteristik Individu, Kewirausahaan, dan Gaya Kepemimpinan terhadap Kemampuan Usaha serta Keberhasilan Usaha pada Usaha Kecil Batik di Jawa Tengah [disertasi]. Malang : Universitas Merdeka Malang.

Okpara FO. 2007. The value of creativity and innovation in entrepreneurship; university of Gondar, Ethiopia. Journal of 
Asia Entrepreneurship and Sustainability. 3(2):1-14.

Pambudy R. 2010. Membangun Entrepreneur Agribisnis yang Berdayasaing. Di dalam: Baga L M, Fariyanti A, Jahroh S, editor. Kewirausahaan dan Dayasaing Agribisnis. Bogor (ID): IPB Press.

Puspitasari. 2013. Pengaruh Perilaku Kewirausahaan Petani Anggrek terhadap Kinerja Usaha: Kasus di Kecamatan Gunung Sindur dan Parung, Kabupaten Bogor, dan Kecamatan Serpong, Kota Tangerang Selatan. [tesis]. Bogor (ID): Institut Pertanian Bogor.

SIPSN (Sistem Informasi Pelakuan Sampah Nasional). 2019. sistem informasi pengelolaan sampah nasional. [diunduh 2020 Okt 06]. Tersedia pada: http://sipsn.menlhk.go.id/

Smith-Hunter AE. 2006. Women Entrepreneurs Across Racial Lines, Issues of Human Capital, Financial Capital and Network Structures. Northampton (US): Edward Elgar Publishing Inc.

Solihin MM. 2018. Pengelolaan Sampah Berkelanjutan melalui Bank Sampah di Desa Ragajaya, Kabupaten Bogor, Provinsi Jawa Barat, Indonesia. Internasional Journal of Progressive Sciences and Technologies. Vol.9 No.2.

Sumantri B. 2013. Pengaruh Jiwa Kewirausahaan Terhadap Kinerja Usaha Pengelola bank sampah Wirausaha Pada Industri Pangan Perumahan di Bogor [tesis]. Bogor (ID): Institut Pertanian Bogor.

Suryana. 2003. Kewirausahaan Pedoman Praktis: Kiat dan Proses Menuju Sukses. Jakarta (ID): Salemba Empat.

Timmons JA, Spinelli S. 2007. New Venture Creation: Entrepreneurship for The 21st Century. Singapore (SG): Mc Graw Hill Companies Inc.

Unilever Indonesia. 2013. Buku panduan sistem bank sampah dan 10 kisah sukses. Yayasan unilever Indonesia. https://www.unilever.co.id/id/Images /buku-panduan-sistem-bank-sampah10-kisah-sukses-ina-id_tcm1310514974_id.pdf

Wijanto SH. 2008. Structural Equation Modelling dengan LISREL 8.8. Yogyakarta(ID): Graha Ilmu.

Wulandari D, Utomo SH, Narmaditya BS. 2017. Waste Bank: Waste Management Model in Improving Local Economy. International Journal of Energy Economics and Policy. 7(3), 36-41. 